\title{
CORRELATION OF THYROID-STIMULATING HORMONE AND PROLACTIN LEVELS IN NON-PREGNANT FEMALE
}

\author{
SULEKHA SINHA ${ }^{1 *}$, ANUPAMA HEGDE ${ }^{2}$, POORNIMA A MANJREKAR ${ }^{2}$, RUKMINI MS $^{2}$ \\ ${ }^{1}$ Department of Biochemistry, IQ City Medical College, Durgapur, West Bengal, India. ${ }^{2}$ Department of Biochemistry, Kasturba Medical \\ College, Mangalore, Karnataka, India. Email: drsulekhasinha@gmail.com
}

Received: 20 February 2020, Revised and Accepted: 24 February 2020

\section{ABSTRACT}

Objective: The objective of the study was to correlate prolactin (PRL) levels with different levels of thyroid-stimulating hormone (TSH).

Methods: The study included 221 non-pregnant females of the age group of 16-43 years. TSH and PRL were assayed. Subjects were divided into three groups based on TSH levels, namely, low, normal, and high TSH levels and results compared.

Statistical analysis: The comparison between different groups was done using test ANOVA. Correlation between TSH and PRL was established using Pearson's correlation test.

Results: Five subjects in Group- 1 with low TSH values (mean $0.096 \pm 0.08 \mu \mathrm{IU} / \mathrm{ml}$ ) had PRL $9.8 \pm 6.25$ ng/dl, 186 subjects in Group- 2 with normal TSH values (mean 1.98 $\pm 0.94 \mu \mathrm{IU} / \mathrm{ml}$ ) had PRL $16.58 \pm 8.78 \mathrm{ng} / \mathrm{dl}$, and in Group-3 with high TSH values (mean $6.45 \pm 3.91 \mu \mathrm{IU} / \mathrm{ml}$ ) had PRL $26.53 \pm 15.98 \mathrm{ng} / \mathrm{dl}$. p value for TSH is $<0.001$ (significant) and for PRL also is $<0.001$ (significant). Positive correlation has been found in overall 221 subjects between TSH and PRL with correlation coefficient $r=0.239$ and $\mathrm{p}=0.01$ (significant).

Conclusion: PRL levels were higher in group with high TSH values. In most previous studies (subjects with established subclinical or overt hypothyroid), PRL was found higher with higher TSH levels. This study showed strong positive association between TSH and PRL irrespective of the thyroid status.

Keywords: Thyroid-stimulating hormone, Prolactin, Infertility.

(C) 2020 The Authors. Published by Innovare Academic Sciences Pvt Ltd. This is an open access article under the CC BY license (http://creativecommons. org/licenses/by/4. 0/) DOI: http://dx.doi.org/10.22159/ajpcr.2020.v13i4.36958

\section{INTRODUCTION}

Hypothyroidism a very common clinical syndrome results from thyroid hormone deficiency. Hypothyroidism, in turn, slows down the generalized metabolic process [1]. Hyperprolactinemia may result from different causes, namely, hypothyroidism, medication, and pituitary disorders. Hyperprolactinemia may result from primary hyperthyroidism mediated by several mechanisms [2].

The thyroid-stimulating hormone (TSH) and prolactin are under the control of central hypothalamopituitary axis. Hyperprolactinemia is a common condition encountered in hypothyroidism and infertility. This may be due to - (i) a compensatory increase in the discharge of central hypothalamic thyrotropin-releasing hormone, which results in stimulation of prolactin (PRL) secretion [3], (ii) decreased PRL elimination from the systemic circulation [3,4], (iii) decreased sensitivity to the suppressant effect of dopamine on PRL synthesis [5], and (iv) increased PRL messenger RNA levels in the presence of lower thyroid hormone levels [6].

This study was conducted to correlate different levels of TSH and PRL irrespective of thyroid status.

\section{METHODS}

The study was conducted at Kasturba Medical College and Hospital, Mangalore, over a period of 8 months from January 2012 to August 2012. The study group comprised 221 non-pregnant female in the age group of 16-43 years visiting the infertility clinic. Proper consent from subject was taken. The $5 \mathrm{ml}$ of blood was drawn with all aseptic measures. PRL and TSH were measured by electrochemiluminescence immunoassay method using autoanalyzer COBAS e411. Subjects were divided into three groups based on their TSH levels as follows: Group 1 - low TSH levels $(<0.4 \mu \mathrm{IU} / \mathrm{ml})$, Group 2 - normal TSH levels (0.4-4.27 $\mu \mathrm{IU} / \mathrm{ml})$, and Group 3 - high TSH levels (>4.27 $\mu \mathrm{IU} / \mathrm{ml})$.

The comparison between three groups was done using ANOVA test. The correlation of PRL levels with TSH was performed using Pearson's correlation test statistically.

\section{RESULTS}

The mean TSH and PRL levels in all the three groups are displayed in Table 1, Fig. 1. The correlation between TSH and PRL was found significantly positive with $\mathrm{r}=0.239$ and $\mathrm{p}<0.001$ (Fig. 2).

\section{DISCUSSION}

In the current study involving different ranges of TSH levels from 0.045 to $10.39 \mu \mathrm{IU} / \mathrm{L}$, a statistically significant positive association was found with PRL $(\mathrm{p}<0.001)$ and a positive trend was observed $(\mathrm{r}=0.239)$. In most previous studies demonstrating a positive association were the subjects with established subclinical or overt hypothyroid patients [6]. The altered high TSH levels can alter the PRL levels.

Zeliha et al. [2] studies found the similar significant positive association of TSH and PRL ( $p=0.003$ ). They also found that $36 \%$ of overt hypothyroid and $22 \%$ of subclinical hypothyroid patients had increased PRL levels. Raber et al. [7] also noticed hyperprolactinemia in $8 \%$ of hypothyroid patients, but pregnancy and lactating women were included in the study. Meir et al. [8] found higher PRL in 19\% of subclinical hypothyroid patients. They also noticed normalization of PRL 
Table 1: TSH and PRL levels in three groups

\begin{tabular}{llll}
\hline & Group-1 $(\mathbf{n = 8})$ & Group-2 (n=183) & Group-3 (n=30) \\
\hline TSH $(\mu \mathrm{IU} / \mathrm{ml})($ mean $\pm \mathrm{SD})$ & $0.096 \pm 0.08$ & $1.98 \pm 0.94$ & $6.45 \pm 3.91$ \\
PRL $(\mathrm{ng} / \mathrm{ml})($ mean $\pm \mathrm{SD})$ & $9.8 \pm 6.25$ & $16.58 \pm 8.78$ & $26.53 \pm 15.98$ \\
\hline
\end{tabular}

TSH: Thyroid-stimulating hormone, SD; Standard deviation, PRL: Prolactin

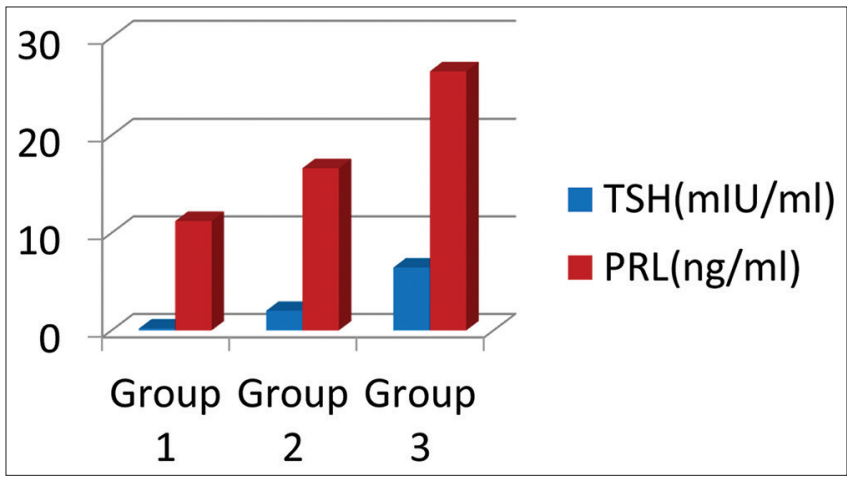

Fig. 1: Serum thyroid-stimulating hormone and prolactin levels among the three groups

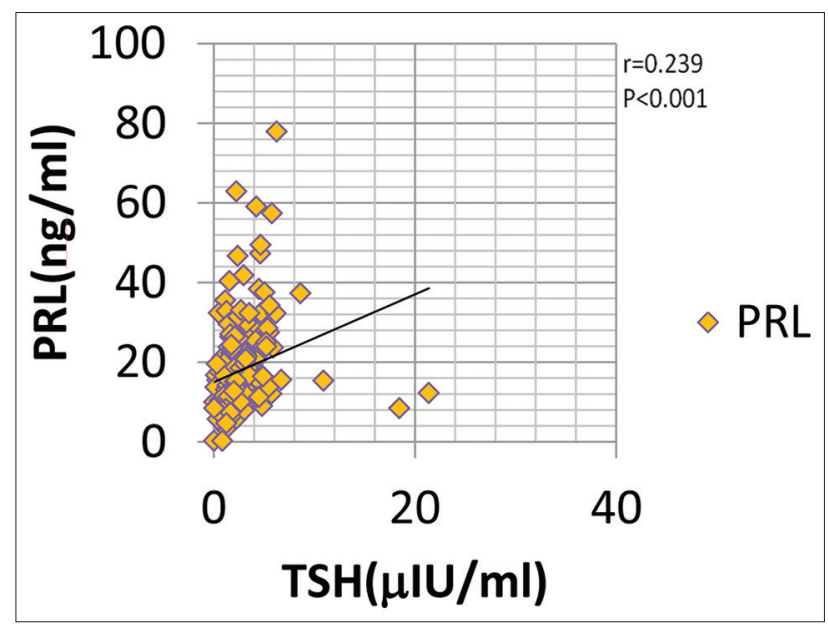

Fig. 2: Correlation of serum thyroid-stimulating hormone and prolactin levels

levels after treatment with L-thyroxine. In studies by Shrestha et al. [9], positive association was observed between PRL, body mass index, and TSH whereas negative with fT3 and fT4. Sharma et al. [10] observed hyperprolactinemia highest in primary hypothyroidism followed by subclinical hypothyroidism and euthyroid individuals. They also noticed significant positive association between TSH and PRL in subclinical hypothyroidism and primary hypothyroidism. Anwary et al. [11] found that only $36 \%$ of subfertile women had normal serum PRL and $56 \%$ of same normal TSH. The study of hormonal status is very important in diagnosis and initiating treatment of infertility [12,13].

However, the positive trend was observed and the hypothesis framed can be tested in the continuation study involving exclusion of other causes of hyperprolactinemia.

\section{CONCLUSION}

The thyroid function tests may be considered in evaluation in case of hyperprolactinemia or in infertility profile.

\section{AUTHORS' CONTRIBUTIONS}

Dr. Sulekha Sinha - doing the research, Dr. Anupama Hegde - guiding and writing of article, Dr. Poornima A Manjrekar - guiding and writing of article, Dr. Rukmini MS - guiding and writing of article.

\section{CONFLICTS OF INTEREST}

None.

\section{REFERENCES}

1. Khan MA, Majumder I, Hoque MM, Fariduddin M, Mollah FH, Arslan MI. Lipid profile in hypothyroid patients: A cross sectional study. Med Today 2013;25:21-4.

2. Hekimsoy Z, Kafesçiler S, Güçlü F, Ozmen B. The prevalence of hyperprolactinaemia in overt and subclinical hypothyroidism. Endocr J 2010;57:1011-5.

3. Prabhakar VK, Davis JR. Hyperprolactinaemia. Best Pract Res Clin Obstet Gynaecol 2008;22:341-53.

4. Serri O, Chik CL, Ur E, Ezzat S. Diagnosis and management of hyperprolactinemia. CMAJ 2003;169:575-81.

5. Foord SM, Peters JR, Dieguez C, Jasani B, Hall R, Scanlon MF. Hypothyroid pituitary cells in culture: An analysis of thyrotropin and prolactin responses to dopamine (DA) and DA receptor binding. Endocrinology 1984;115:407-15.

6. Davis JR, Lynam TC, Franklyn JA, Docherty K, Sheppard MC. Triiodothyronine and phenytoin reduce prolactin messenger RNA levels in cultured rat pituitary cells. J Endocrinol 1986;109:359-64.

7. Raber W, Gessl A, Nowotny P, Vierhapper H. Hyperprolactinaemia in hypothyroidism: Clinical significance and impact of TSH normalization. Clin Endocrinol (Oxf) 2003;58:185-91.

8. Meier C, Christ-Crain M, Guglielmetti M, Huber P, Staub JJ, Müller B. Prolactin dysregulation in women with subclinical hypothyroidism: Effect of levothyroxine replacement therapy. Thyroid 2003;13:979-85

9. Shrestha S, Neupane S, Gautam N, Dubey RK, Jha AC, Doshi NR, et al. Association of thyroid profile and prolactin level in patient with secondary amenorrhea. Malays J Med Sci 2016;23:51-6.

10. Sharma LK, Sharma N, Gadpayle AK, Dutta D. Prevalence and predictors of hyperprolactinemia in subclinical hypothyroidism. Eur J Intern Med 2016;35:106-10.

11. Anwary SA, Fatima P, Alfazzaman M, Mahzabin Z, Rahman MM, Bari N. Serum prolactin level of subfertile women. Mymensingh Med J 2016;25:91-5

12. Kataria J, Gill GK, Kaur M. Interrelationship of thyroid hormones, obesity, and prolactin in infertile women. Asian J Pharm Clin Res 2018;11:136-7.

13. Hakeim HK, Jebur IM, Rahim AI. Sirt6 is correlated with estradiol in women with in vitro fertilization failure. Int J Pharm Pharm Sci 2016;8:184-8. 